\title{
First records of coalescence and hypomerism in Tonicia atrata (Polyplacophora, Chitonidae) in the southwestern Atlantic Ocean
}

\author{
Camila GUILLÉN ${ }^{1} \&$ Diego URTEAGA ${ }^{2}$
}

\begin{abstract}
${ }^{1}$ Facultad de Ciencias Naturales y Museo, Universidad Nacional de La Plata. Avenida 122 y 60, (1900) La Plata, Argentina. ${ }^{2}$ Museo Argentino de Ciencias Naturales, CONICET. Av. Ángel Gallardo 470, (C1405DJR) Ciudad

Autónoma de Buenos Aires, Argentina; e-mail: diegourteaga@macn.gov.ar.
\end{abstract}

\begin{abstract}
The first cases of anomalies in the number of shell-plates in Tonicia atrata (Sowerby II, 1840) are herein reported on the basis of three specimens from Zaratiegui Bay, Tierra del Fuego, Argentina (54 50 '53' S, $68^{\circ} 29^{\prime} 7$ ' W): two cases of coalescence (one symmetrical and another one asymmetrical) and a case of hypomerism. The abnormal specimens bore less ctenidia than physiological conspecific specimens of similar size. The symmetrical coalescent specimen and the hypomeric individual were significantly wider (higher width/length ratio) than physiological specimens. Nevertheless, the reported abnormalities seem to have no effect on general growth, since the body size of the abnormal specimens were close to the largest physiological ones found in the same locality.
\end{abstract}

Key words: teratology, morphology, Mollusca, Argentina, Patagonia.

Resumen: Primeros registros de coalescencia e hipomerismo en Tonicia atrata (Polyplacophora, Chitonidae) en el Océano Atlántico sudoccidental. Se registran aquí los primeros casos de anomalías en el número de placas en ejemplares de Tonicia atrata (Sowerby II, 1840), sobre la base de tres ejemplares hallados en Bahía Zaratiegui, Tierra del Fuego, Argentina (5450'53”' S, 68 29'7' O): dos casos de coalescencia (uno simétrico; el otro asimétrico) y un caso de hipomerismo. Los ejemplares anormales poseían menos ctenidios que los coespecíficos fisiológicos de similar tamaño. El ejemplar coalescente simétrico y el hipomérico eran significativamente más anchos (mayor relación ancho/largo) que los individuos fisiológicos. Sin embargo, las aberraciones registradas no parecen haber afectado el crecimiento general de los individuos anormales, ya que sus tallas fueron similares a la de los ejemplares fisiológicos más grandes encontrados en la misma localidad.

Palabras clave: teratología, morfología, Mollusca, Argentina, Patagonia.

\section{INTRODUCTION}

Members of the Class Polyplacophora normally bear eight dorsal shell-plates. This ordinary number can be affected by infrequent abnormalities that can be classified as: Hypomerism (less than eight shell-plates), Hypermerism (more than eight shell-plates), Coalescence (two or more shell-plates fused), and Splitting (at least one shell-plate split), according to Dell'Angelo \& Schwabe (2010).

About 380 anomalous polyplacophoran specimens are known worldwide, belonging in 130 different species, from the first records by Crozier (1919) and Pelseneer (1919) to the recent study by Torres et al. (2018), among others.

The only teratological records from South America came from the southeastern Pacific (Peña, 1977; Peña \& Castro, 1982; Gálvez Herrera, 1991; Torres et al., 2018). This paper is the first contribution to this topic from the southwestern Atlantic.

Despite their pathological shell-plates, the abnormal specimens seem to be almost physiological regarding their growth.

Tonicia atrata (Sowerby II, 1840) is a medium to large sized species, up to $8.5 \mathrm{~cm}$ long (Reid \& Osorio, 2000), known to be distributed from Islas Malvinas (type locality), Magellan Strait, Tierra del Fuego, and the Pacific coast up to Puerto Montt ( $41^{\circ} 28^{\prime}$ S, $\left.72^{\circ} 56^{\prime} \mathrm{W}\right)$; bathymetric range: 0-10 m (Castellanos, 1988; Kaas et al., 2006; Sirenko, 2006); Schwabe et al. (2006) extended its range up to $36 \mathrm{~m}$ deep. Tonicia atrata was recently cited from northern Chile $\left(27^{\circ} \mathrm{S}\right.$ : Araya \& Araya, 2015) and, as an alien species, from Spain and Canary islands (Arias \& Anadón, 2013).

The aim of this publication is to report the first specimens of Tonicia atrata with less than eight shell-plates and to compare the shape of 
these specimens and their number of ctenidia with the same features of physiological specimens from the southwestern Atlantic.

\section{MATERIAL AND METHODS}

The abnormal specimens were sampled by the second author through scuba diving in Zaratiegui Bay, Tierra del Fuego National Park, Argentina (54 50'53' S, 68 $29^{\circ} 7^{\prime \prime}$ W) (Fig. 1), 2-4 m deep, in March 2010. The individuals were preserved in $96 \%$ ethanol after collection.

They were identified by morphological characters under a Zeiss Discovery V20 stereoscopic microscope. Shell-plates were extracted to identify the nature of each aberration. Physical features were measured with a digital caliper (precision $\pm 0.01 \mathrm{~mm}$ ). Total length (L) was considered from the anterior margin of the head shell-plate to the posterior margin of the tail shell-plate, to avoid the artifact caused by perinotum bending; as some specimens were curved, a flexible cord was used to cover the distance to be measured. Total width (W) was interpreted as the distance between the lateral margins of the widest shell-plate. Dorsal elevation was considered as the average height / width ratio of intermediate shell-plates. Ctenidia counting was made under the stereoscopic microscope.

Measurements of length and width of the aberrant specimens were compared to those of physiological specimens of similar length, collected at the same locality: 6 specimens sampled in March 2010, and 24 ones sampled in February 2014. Shape comparison between physiological and abnormal specimens was based upon width / length ratio $(\mathrm{W} / \mathrm{L})$.

Number of ctenidia was also compared between aberrant and physiological specimens of Tonicia atrata. It was considered as the average between sides (C) since an unexplained asymmetry was found. This comparison was based on 26 individuals from Zaratiegui Bay and 4 from Golondrina Bay ( $\left.54^{\circ} 50^{\prime} 30.18^{\prime \prime} \mathrm{S}, 68^{\circ} 21^{\prime} 49.26^{\prime \prime} \mathrm{W}\right)$, both samples collected in February 2014.

Normal specimens in these comparisons were selected from a total of 115 conspecific individuals sampled in both localities during two field trips (March 2010 and February 2014).

Intervals of confidencial $95 \%\left(\mathrm{IC}_{95}\right)$ were calculated from physiological specimens in order to compare $\mathrm{W} / \mathrm{L}$ and $\mathrm{C}$ between these and the aberrant individuals. Pearson linear correlation analysis was performed to test the dependence between L (continuous independent variable) and $\mathrm{C}$ (continuous dependent variable). Normal probability plots of $\mathrm{L}, \mathrm{W} / \mathrm{L}$, and $\mathrm{C}$ of physiological specimens were obtained to check normal distribution.

Abnormal specimens analyzed in this work were deposited in the Colección de Invertebrados at the Museo Argentino de Ciencias Naturales, Buenos Aires, Argentina (Collection number: MACN-In 41249).

No other aberrant individuals of Tonicia atrata were found either in March 2010, during further sampling in to Zaratiegui Bay (February 2014) or among more than 2,000 specimens of 20 species from the southwestern Atlantic Ocean revised at MACN, MLP, MNHN, MORG, MZUSP, MNRJ and material collected by the second author.

Acronyms - MACN: Museo Argentino de Ciencias Naturales. Argentina; MLP: Museo de La Plata. Argentina; MNHN; Museo Nacional de Historia Natural. Uruguay; MORG: Museu Oceanográfico "Prof. Eliézer de Carvalho Rios". Brazil; MZUSP, Museu de Zoologia da Universidade de São Paulo. Brazil; MNRJ: Museu Nacional / Universidade Federal do Rio de Janeiro. Brazil.

\section{RESULTS}

\section{Physiological specimens}

Figure 2 shows a dispersion graph of length and width for 30 normal individuals of similar size to aberrant specimens, collected at Zaratiegui Bay during March 2010 and February 2014. Average W/L of these non-aberrant specimens was $0.34 \pm \mathrm{IC}_{95} 0.01$, and mean $\mathrm{C}$ value was $37.18 \pm \mathrm{IC}_{95} 1.47$. There was not a meaningful incidence of the body length on the number of ctenidia within the analyzed size range, since the correlation between these variables was not significant (Pearson's $\mathrm{r}=-0.15 ; \mathrm{p}=0.42$ ).

\section{Abnormal individuals}

The abnormalities of the three specimens of Tonicia atrata found at Zaratiegui Bay were identified as:

Coalescence. Two specimens bore fused shellplates, with different symmetries:

Asymmetric fusion of shell-plates III-IV (MACNIn 41249a). Shell-plate IV is represented by only its right side (Fig. 3). Size: $3.08 \mathrm{~cm}$ long $\times 1.04 \mathrm{~cm}$ wide $(\mathrm{W} / \mathrm{L}=0.338)$; dorsal elevation: 0.42. Ctenidia: 34 on the left side; 37 on the right side $(\mathrm{C}=35.5)$. 


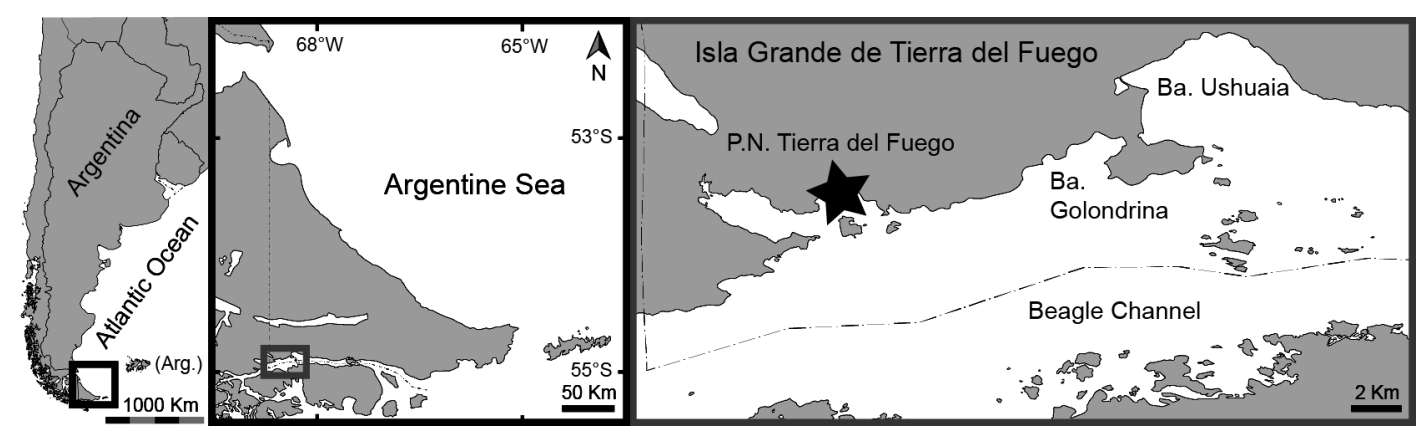

Fig. 1. Map of sampled area. Star mark: location of Zaratiegui Bay.

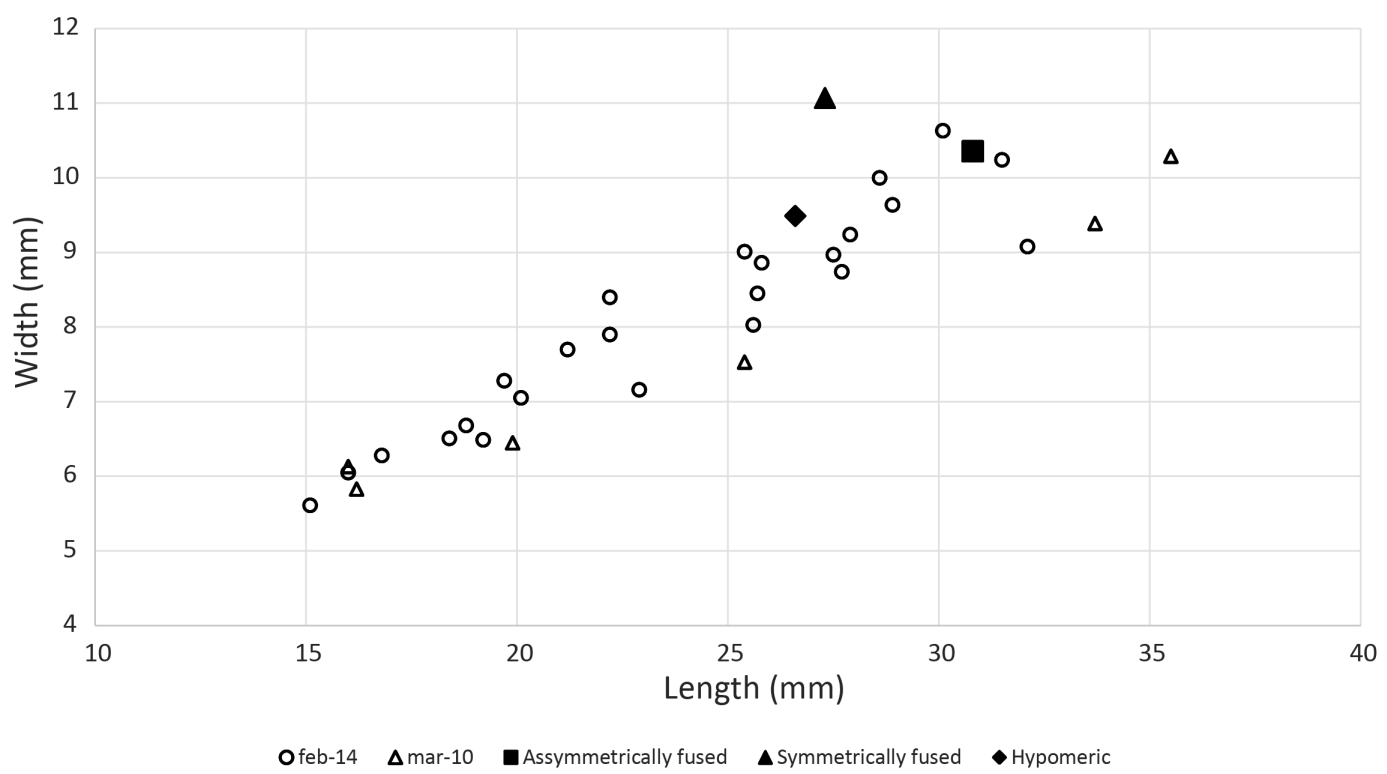

Fig. 2. Scatter plot of length and width of physiological specimens of Tonicia atrata collected in Zaratiegui Bay in March $2010(\mathrm{~N}=6)$ and February $2014(\mathrm{~N}=24)$, and the three anomalous specimens reported in this paper.

Symmetric fusion of shell-plates V-VI (MACN-In 41249b). The remnants of shell-plate VI consist in both lateral areas and a ventral vestige on the inner surface, below its jugal area (Fig. 4). Size: $2.73 \mathrm{~cm}$ long $\times 1.11 \mathrm{~cm}$ wide $(\mathrm{W} / \mathrm{L}=$ 0.407); dorsal elevation: 0.43 . Ctenidia: 37 on the left side; 30 on the right side $(\mathrm{C}=33.5)$.

Hypomerism. One specimen bearing seven shell-plates (MACN-In 41249c), each one with physiological appearance (Fig. 5). Size: $2.66 \mathrm{~cm}$ long x $0.95 \mathrm{~cm}$ wide $(\mathrm{W} / \mathrm{L}=0.357)$; dorsal elevation: 0.35 . Ctenidia: 35 on the left side; 31 on the right side $(\mathrm{C}=33.0)$.

\section{DISCUSSION}

Anomalies in the number of shell-plates of chitons are uncommon (Dell'Angelo \& Tursi,
1990). The three teratological specimens collected at Zaratiegui Bay, Tierra del Fuego, are the first cases for Tonicia atrata and the first record of anomalous polyplacophorans from the southwestern Atlantic Ocean.

The reported anomalies seem to have no effect on the general growth of the individuals, since the aberrant specimens reached a size close to the largest physiological ones found in the same locality. However, the coalescent specimen with symmetric fusion (MACN-In $41249 \mathrm{~b}$ ) and the hypomeric specimen (MACNIn 41249 c) were wider than any physiological one (W/L higher than the upper boundary of the 95\% IC for the normal specimens: 0.35) (Fig. 2).

Vertical segregation in size was described for some species of Polyplacophora (Otaíza \& Santelices, 1985). Tonicia atrata is a quite variable 


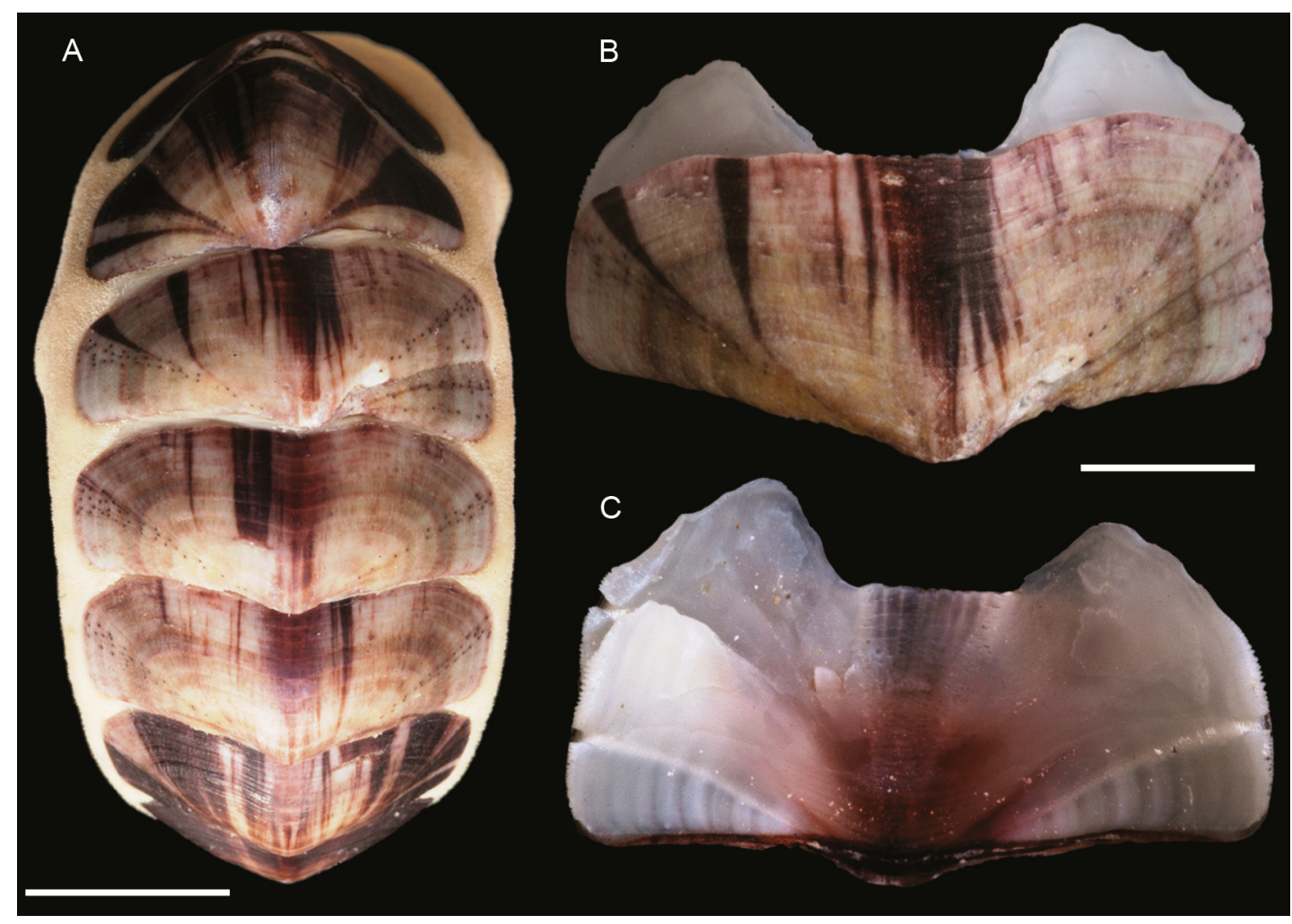

Fig. 3. Specimen of Tonicia atrata showing asymmetric fusion of shell-plates III-IV (MACN-In 41249a). A. Dorsal view of the whole specimen. B. Isolated III+IV shell-plate in dorsal view. C. Ventral view of B. Scale bars: $\mathbf{A}=$ $0.5 \mathrm{~cm} ; \mathbf{B}, \mathbf{C}=250 \mu \mathrm{m}$.

species in terms of size. The type material was one inch long (Sowerby II, 1840); $2.5 \mathrm{~cm}$ according to Pilsbry (1892), with no reference to collection depth. Instead, Sirenko (2006) reported $7 \mathrm{~cm}$ long specimens in the same locality (Islas Malvinas) between 9 and $36 \mathrm{~m}$ deep. Our material from 2-4 $\mathrm{m}$ deep in Tierra del Fuego was closer to the size of the type material.

According to Taki (1932), the body length shows alterations closely correlated with the number of shell-plates, but the number of ctenidia remains unmodified in abnormal chitons. However, our abnormal specimens bore significantly less ctenidia than the physiological conspecific individuals ( $\mathrm{C}$ less than the lowest limit of the $\left.\mathrm{CI}_{95 \%}: 35.71\right)$.

It is not possible to extrapolate these findings to true relationships between shell-plate abnormalities and those morphological features, due to the low number of cases, each one bearing a different anomaly. Nevertheless, it is worth mentioning that Kniprath (1980) and Sirenko \& Kashenko (1990) stated that temperature and salinity variations affect the development of Po- lyplacophora larvae; and Langer (1978) found a correlation between population density and abnormal shell-plate number. We have no data on population density, community composition or other factors allowing advancing any further hypothesis on our findings.

\section{ACKNOWLEDGEMENTS}

We thank curators of the visited museum collections, especially Alejandro Tablado (Museo Argentino de Ciencias Naturales) and Gustavo Darrigran (Museo de La Plata). We also thank Alejandro Valenzuela who granted the permission (034-CPA), on behalf of the Administración de Parque Nacionales, to sample in Tierra del Fuego National Park. The authors wish to express their gratitude to Miguel Griffin (Universidad Nacional de La Plata) who helped to improve the English version of the manuscript, to Gabriela Palomo (Museo Argentino de Ciencias Naturales) who provide her statistic expertise, and to Felipe Torres, another anonymous reviewer and Néstor Cazzaniga (associated editor) for their 


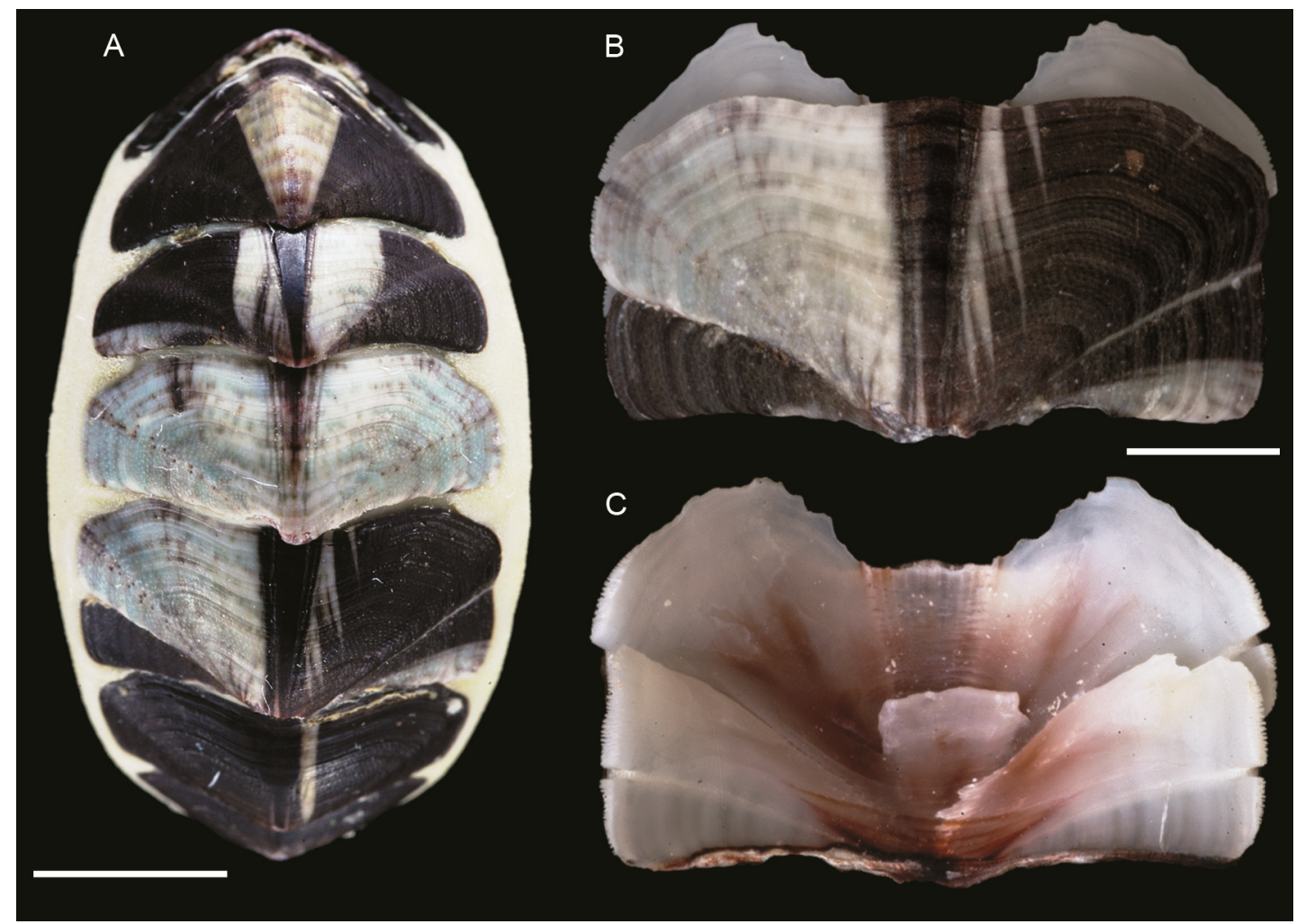

Fig. 4. Specimen of Tonicia atrata showing symmetric fusion of shell-plates V-VI (MACN-In 41249b). A. Dorsal view of the whole specimen. B. Isolated V+VI shell-plate in dorsal view. C. Ventral view of B. Scale bars: $\mathbf{A}=0.5$ $\mathrm{cm} ; \mathbf{B}, \mathbf{C}=250 \mu \mathrm{m}$.

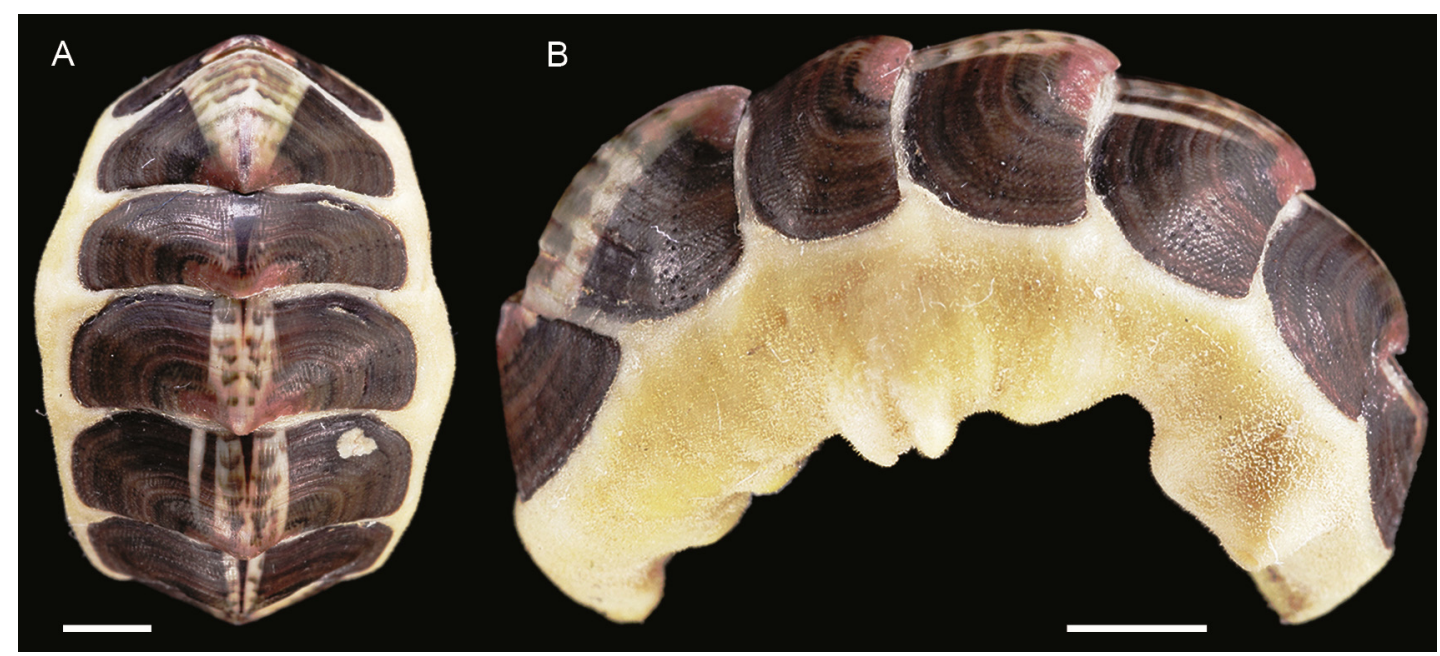

Fig. 5. Seven-plate specimen of Tonicia atrata showing hypomerism (MACN-In 41249c). A. Dorsal view of the whole specimen. B. Lateral view of A. Scale bar: $250 \mu \mathrm{m}$. 
accurate suggestions. This contribution was supported in part by Project PICT 2013-1999 from the Agencia Nacional de Promoción Científica y Tecnológica, Argentina. We acknowledge funding by the Consejo Nacional de Investigaciones Científicas y Técnicas (CONICET) of Argentina, to which the second author belongs.

\section{REFERENCES}

Araya, J.F. \& M.E. Araya. 2015. The shallow-water chitons (Mollusca, Polyplacophora) of Caldera, region of Atacama, northern Chile. Zoosystematics and Evolution 91: 45-58. doi: 10.3897/zse.91.8536.

Arias, A. \& N. Anadón. 2013. Tonicia atrata and Chiton cumingsii (Polyplacophora: Chitonidae): First records in European waters. Zootaxa 3626(4): 593596. doi:10.11646/zootaxa.3626.4.14

Castellanos, Z.J.A. de. 1988. Catálogo descriptivo de la malacofauna marina magallánica 1. Los placóforos. La Plata: Comisión de Investigaciones Científicas de la Provincia de Buenos Aires. 41 pp.

Crozier, W.J. 1919. Coalescence of the shell-plates in chiton. The American Naturalist 53(626): 278-279.

Dell'Angelo, B. \& A. Tursi. 1990. Abnormalities in chiton shell-plates. Oebalia,14(1): 1-14.

Dell'Angelo, B. \& E. Schwabe. 2010. Teratology in chitons (Mollusca, Polyplacophora): A brief summary. Bollettino Malacologico 46: 9-15.

Gálvez Herrera, O. 1991. Hipomería en Plaxiphora fernandezi Thiele, 1909 (Mollusca, Polyplacophora). Noticiario Mensual del Museo Nacional de Historia Natural 318: 3-4.

Kaas, P., R. Van Belle \& H.L. Strack. 2006. Monograph of living chitons (Mollusca: Polyplacophora). 6. Suborder Ischnochitonina (concluded):Schizochitonidae \& Ischnochitonidae. Additions to Volumes 1 - 5. Leiden - New York Köln: E.J. Brill. 464 pp.

Kniprath, E. 1980. Ontogenetic plate and plate field development in two chitons, Middendorffia and Ischnochiton. Wilhelm Roux's Archives of Developmental Biology 189: 97-106. doi: https:// doi.org/10.1007/BF00848498.

Langer, P.D. 1978. Abnormality of shell plates in three chitons from New England. The Veliger 21(2): 274-275.

Otaíza, R.D. \& B. Santelices. 1985. Vertical distribution of chitons (Mollusca: Polyplacophora) in the rocky intertidial zone of central Chile. Journal of
Experimental Marine Biology and Ecology 86: 229240.

Pelseneer, P. 1919. La métamérie et l'hypomérie chez les chitons. Annales de la Société Royale Zoologique et Malacologique de Belgique 50: 41-43.

Peña, R. 1977. Hipomería en Chiton granosus Frembly, 1827. Noticiario Mensual Museo de Historia Nacional 253: 9-10.

Peña, R. \& R. Castro. 1982. Coalescencia de valvas en Chiton granosus Frembly, 1827. Noticiario Mensual Museo de Historia Nacional 305: 8-9.

Pilsbry, H.A. 1892. Manual of conchology, structural and systematic: with illustrations of the species. Series 1, vol. 14. Philadelphia: Academy of Natural Sciences, 350 pp., 68 pl. doi: https://doi.org/10.5962/ bhl.title.10543.

Reid, D.G. \& C. Osorio. 2000. The shallow-water marine Mollusca of the Estero Elefantes and Laguna San Rafael, southern Chile. Bulletin of the Natural History Museum, London (Zoology) 66(2): 109-146. http://direct.biostor.org/reference/113684.

Schwabe, E., G. Foersterra, V. Haeussermann, R.R. Melzer \& M. Schroedl. 2006. Chitons (Mollusca: Polyplacophora) from the southern Chilean Comau Fjord, with reinstatement of Tonicia calbucensis Plate, 1897. Zootaxa 1341(1): 1-27. doi: http:// dx.doi.org/10.11646/zootaxa.1341.1.1.

Sirenko, B.I. 2006. Report on the present state of our knowledge with regard to the chitons (Mollusca: Polyplacophora) of the Magellan Strait and Falkland Islands. Venus 65(1-2): 81-89.

Sirenko, B.I. \& S.D. Kashenko. 1990. Larval development of Ischnochiton hakodadensis Pilsbry (Polyplacophora, Ischnochitonidae) under normal conditions and at salinity changes. Biologia Morya 1: $43-51$.

Sowerby, G.B. II. 1840. Descriptions of some new chitons. Magazine of Natural History, conducted by Edward Charlesworth (n.s.) 4: 287-294, suppl. pl. 216.

Taki, I. 1932. On some cases of abnormality of the shellplates in chitons. Memoirs of the College of Science Kyoto Imperial University (B) 8(1): 27-64, 22 pl.

Torres, F.I., C.M. Ibáñez, V.E. Sanhueza \& M.C. PardoGandarillas. 2018. Mollusk freaks: new teratological cases on marine mollusks from the South Pacific Ocean. Latin American Journal of Aquatic Research 46(4): 683-689. doi: 10.3856/vol46-issue4fulltext-5.

Doi: 10.22179/REVMACN.21.610

Recibido: 5-XI-2018

Aceptado: 15-V-2019 